\title{
Qualitative and quantitative determination of water in airborne particulate matter
}

\author{
S. Canepari ${ }^{1,2}$, C. Farao ${ }^{1}$, E. Marconi ${ }^{1}$, C. Giovannelli ${ }^{1}$, and C. Perrino ${ }^{2}$ \\ ${ }^{1}$ Department of Chemistry, Sapienza University of Rome, P.le Aldo Moro, 5, Rome, 00185, Italy \\ ${ }^{2}$ CNR Institute of Atmospheric Pollution Research, Via Salaria, Km 29300, Monterotondo St., Rome, 00015, Italy
}

Correspondence to: S. Canepari (silvia.canepari@uniroma1.it)

Received: 2 October 2012 - Published in Atmos. Chem. Phys. Discuss.: 18 October 2012

Revised: 16 January 2013 - Accepted: 22 January 2013 - Published: 1 February 2013

\begin{abstract}
This paper describes the optimization and validation of a new simple method for the quantitative determination of water in atmospheric particulate matter (PM). The analyses are performed by using a coulometric Karl-Fisher system equipped with a controlled heating device; different water contributions are separated by the application of an optimized thermal ramp (three heating steps: $50-120^{\circ} \mathrm{C}, 120$ $180^{\circ} \mathrm{C}, 180-250^{\circ} \mathrm{C}$ ).
\end{abstract}

The analytical performance of the method was verified by using standard materials containing $5.55 \%$ and $1 \%$ by weight of water. The recovery was greater than $95 \%$; the detection limit was about $20 \mu \mathrm{g}$. The method was then applied to NIST Reference Materials (NIST1649a, urban particulate matter) and to real $\mathrm{PM}_{10}$ samples collected in different geographical areas. In all cases the repeatability was satisfactory (10-15\%).

When analyzing the Reference Material, the separation of four different types of water was obtained. In real $\mathrm{PM}_{10}$ samples the amount of water and its thermal profile differed as a function of the chemical composition of the dust. Mass percentages of 3-4\% of water were obtained in most samples, but values up to about $15 \%$ were reached in areas where the chemical composition of PM is dominated by secondary inorganic ions and organic matter. High percentages of water were also observed in areas where PM is characterized by the presence of desert dust.

A possible identification of the quality of water released from the samples was tried by applying the method to some hygroscopic compounds that are likely contained in PM (pure $\mathrm{SiO}_{2}, \mathrm{Al}_{2} \mathrm{O}_{3}$, ammonium salts, carbohydrates and dicarboxylic acids) and by comparing the results with those obtained from field samples.

\section{Introduction}

The interaction of water with atmospheric particulate matter (PM) has been described in many research papers, mainly focused on the study of the relationship between relative humidity and water adsorbed on PM and on the effects the interaction with water may exert on the physico-chemical behavior of PM. Because of this interaction, the original physical and chemical features of the atmospheric particles may undergo significant variations, mainly in their size distribution (Swietlicki et al.,1999), optical properties and residence time in the atmosphere (Sloane and Wolfe, 1985; Pilinis et al., 1995; Kreidenweis et al., 2001). Moreover, it is well known that high values of relative humidity (RH) favor the occurrence of acid-base reactions leading to the formation of secondary inorganic salts (Baek et al., 2004; Squizzato et al., 2012). Finally, from the point of view of PM sampling, the amount of adsorbed water affects the solid-vapour equilibria of secondary ammonium salts collected on the filters, a mechanism that is among the main responsible for sampling artifacts (Vecchi et al., 2009). Although in most cases the artifact is negative (loss of $\mathrm{NH}_{4} \mathrm{NO}_{3}$ due to release of $\mathrm{NH}_{3}$ and $\mathrm{HNO}_{3}$ ) (Chow et al., 2005; Yuc et al., 2006; Pathak et al., 2009), in the presence of very high $\mathrm{RH}$ values it becomes positive, as the formation of particulate $\mathrm{NH}_{4} \mathrm{NO}_{3}$ from gaseous $\mathrm{NH}_{3}$ and $\mathrm{HNO}_{3}$ is favored (Gysel et al., 2007; Khlystov et al., 2009; Hu et al., 2011).

Of interest is also the contribution of water to the mass concentration of PM. The presence of considerable amounts of water in PM samples, in fact, causes an increase of PM mass concentration that might be responsible for exceedances of the regulatory limit values. It is worth noting 
that the knowledge of this contribution may be of interest for a correct evaluation of the health effects of PM: water is harmless in itself, but it may cause a relevant variation of the aerodynamic diameter of the particles and thus of their ability to penetrate into the respiratory tree.

Moreover, in many papers attempting PM mass closure, the unidentified mass (difference between gravimetric determination and reconstruction from single chemical analyses) is generally attributed to the presence of water and/or to the difficulty in determining an adequate conversion factors to calculate organic matter $(\mathrm{OM})$ from the measurement of organic carbon (OC) (Balasubramanian et al., 2003; Harrison et al., 2003; Tsyro, 2005; Almeida et al., 2006; Sasaki and Sakamoto, 2006; Perrino et al., 2007; Perrino et al., 2009; Perrone et al., 2012). A quantitative determination of the amount of water collected on the filter would make it possible to distinguish the weight of these two factors and to improve the definition of OC/OM conversion factors.

Finally, the interaction with water seems to play a role in the different performance exhibited by Teflon and quartz membrane filters in sampling PM (Perrino et al., 2012).

In spite of the relevant role played by water in the study of atmospheric PM, a quantitative determination of adsorbed water was attempted only in a few papers. Water content was generally determined by indirect methods, consisting of the differential determination of particle dimension (Dick et al., 2000; Hu et al., 2001; Rees et al., 2004; Stanier et al., 2004; Kitamori et al., 2009) or collected mass amount (Speer et al., 1997; Speer et al., 2003) before and after the exposure to controlled RH conditions. These studies showed that water may constitute up to $20-30 \%$ of the total PM mass and indicated a dependence of the water uptake on the dimensions and chemical composition of the particles. Water adsorption resulted to be relevant for fine particles, characterized by high surface area, and for particles containing water-soluble inorganic salts, mainly ammonium sulphate (Speer et al., 1997; Stanier et al., 2004; Kitamori et al., 2009), and hygroscopic organic species such as dicarboxylic acids (Ansari and Pandis, 2000; Dick et al., 2000; Decesari et al., 2001; Speer et al., 2003). In the paper of Rees et al. (2004), the addition of the water content, measured by Dry-Ambient Aerosol Size Spectrometer (DAASS), to the amount of PM macro-components allowed a significant improvement of the mass closure. It is worth noting, however, that these differential techniques evaluate only the amount of surface-adsorbed water and are not able to give information about further contributions due to structurally-bound water.

To our knowledge, only two papers reporting a direct analytical determination of water on PM filters by the KarlFisher method have been published up to now (Ohta et al., 1998; Tsai et al., 2005). The first one was based on the thermal desorption of water at $150^{\circ} \mathrm{C}$ from Teflon filters sampled for two weeks; the results showed that a percentage of the total $\mathrm{PM}_{2.0}$ mass ranging from $0.4 \%$ to $3.2 \%$ could be attributed to the crystallization water of $\left(\mathrm{NH}_{4}\right)_{2} \mathrm{SO}_{4}, \mathrm{NH}_{4} \mathrm{NO}_{3}$ and $\mathrm{NaCl}$. In the second paper, the water contained on quartz filters conditioned at $60 \% \mathrm{RH}$ was extracted by using anhydrous methyl alcohol; in these conditions water resulted to be the individual component at highest concentration (about $30 \%$ of the total PM mass). In spite of the different operative conditions employed in these two studies, these results demonstrate that the Karl Fisher technique is suitable for determining water in PM samples; the described methods, however, are not appropriate for a routine use in intensive monitoring campaigns because of too high detection limits (Ohta et al., 1998) and/or method complexity (Tsai et al., 2005).

The present work reports the optimization and validation of a new method for the determination of water in atmospheric PM samples, easily applicable to routine field campaigns. The method is based on the use of a thermal ramp for the selective desorption of different water contributions, retained by the sample with different strength. The analysis is carried out by coulometric Karl Fisher (KF) technique. This approach is based on the results of a previous work, where three different water contributions, released at different temperatures, had been identified by analyzing the Certified Material NIST 1649a by thermogravimetry (TG) (Perrino et al., 2012). In that study, however, it was not possible to carry out a quantitative determination of the three contributions because other volatile species were released in the same temperature ranges.

The proposed method has been applied to pure hygroscopic materials that are commonly contained in atmospheric $\mathrm{PM}$ and to real $\mathrm{PM}_{10}$ samples collected in various geographical areas, so as to highlight the relationship between the chemical composition of PM and the thermal behavior of water.

\section{Experimental}

\subsection{Materials}

For the validation of the method we used two standard materials: HYDRANAL Water Standard KF-Oven $220^{\circ} \mathrm{C}-$ $230^{\circ} \mathrm{C}$ (HYD; Fluka Analytical) and Water Standard Oven $1 \%$, (WSO; ACS Merck KGaA), containing $5.55 \pm 0.05 \%$ and $1.0 \pm 0.03 \%$ water, respectively.

$\mathrm{SiO}_{2}, \mathrm{Al}_{2} \mathrm{O}_{3}, \mathrm{NH}_{4} \mathrm{HSO}_{4}, \mathrm{NH}_{4} \mathrm{Cl}, \mathrm{NH}_{4} \mathrm{NO}_{3},\left(\mathrm{NH}_{4}\right)_{2} \mathrm{SO}_{4}$, glucose, lactose, fructose, sucrose, levoglucosan, tartaric acid, citric acid, succinic acid, oxalic acid, phenylalanine were analytical grade (ACS Merck KGaA).

The other materials (Saharan dust, road dust, soot from vehicular exhaust, skin, bacteria, moulds, pollens) were taken directly from the environment and analyzed without any pretreatment.

\subsection{Karl-Fisher analysis}

Karl-Fisher is a well-established analytical technique developed in the first half of the XX century (Fisher, 1935). It 
is based on the quantitative reaction between water and $\mathrm{I}_{2}$, which is generally electrochemically generated inside a cell containing a specific solution. In the coulometric version of the technique, the total amount of water inside the cell is determined by measuring the total electric charge needed to generate $\mathrm{I}_{2}$. Iodine generation stops when the end point of titration is reached. The end point is indicated voltammetrically by the drastic lowering of the voltage difference between the wires of a double Pt electrode.

In this study we used a $831 \mathrm{KF}$ Coulometer (Metrohm AG, Herisau, $\mathrm{CH}$ ) equipped with an oven (874 Oven Sample Processor; Metrohm). The samples are inserted into glass vials $(6 \mathrm{ml}$, Metrohm $)$ and placed inside the oven; water released when heating the sample is transferred to the measurement cell by a carrier gas and measured. This instrumental configuration implies the presence of a signal drift, being unfeasible to eliminate all the water contained in the system (mainly in the carrier gas). In these conditions, the detection of the end point takes into account also the value of the drift.

Karl Fisher reagent (Hydranal-Coulomat AG-Oven, Sigma-Aldrich, $100 \mathrm{~mL}$ ) was used in the titration cell. For transferring the sample from the oven to the measurement cell we used ambient air at the flow rate of $20 \mathrm{~mL} \mathrm{~min}^{-1}$, previously filtered and dried by using molecular sieves $(0.3 \mathrm{~nm}$ pore size, Metrohm AG, Herisau, CH). To avoid clogging of the carrier gas transfer line due to the condensation of species desorbed from PM (e.g.: ammonium salts) the line and the needle entering the titration cell were accurately cleaned every day.

Before each measurement the sample vials were kept in oven at $250^{\circ} \mathrm{C}$ for $12 \mathrm{~h}$, then placed in a desiccator and transferred inside an AtmosBag (Sigma-Aldrich) filled with Argon dried by using molecular sieves. Samples were weighted by using an analytical balance Gibertini E505 (sensitivity $0.01 \mathrm{mg}$; Gibertini Elettronica, Novate Milanese, Milan, I) and put inside the AtmosBag, where they were inserted into the vials.

The instrument used in this study was equipped with a temperature-programmable oven that allows the setting of tailor-made heating ramps. This instrumental feature was necessary to obtain the selective desorption of different water contributes. However, the use of heating ramps required to perform some modifications to the default settings of the instrument software. As previously outlined, the instrument is equipped with an automatic system that identifies the end point of the titration according to the return of the baseline drift to its initial value. When using a thermal ramp, it is necessary to exclude the end point identification, as each return of the drift to the initial value indicates the separation of a different water contribution. As a consequence, the minimum value of the voltage difference between the indicator platinum electrodes was set at $30 \mathrm{mV}$, the limit value of the drift was set at $1 \mu \mathrm{g} \mathrm{min}-1$ and the total duration of the analysis (extraction time) was fixed at $3000 \mathrm{~s}$.
Furthermore, the instrument software calculates the amount of desorbed water by subtracting the contribution due to the baseline drift from the final water amount; the baseline drift contribution is calculated by extrapolating its initial value to the end of the analysis. In our case, the use of the thermal ramp caused the increase of the analytical time with a consequent increase of the drift contribution to the final water amount, which becomes comparable with the amount of water in the PM samples. Also, the drift value is variable, and the influence of this variability on the repeatability of the analytical results also increases with the duration of the analysis. In our conditions, the intra-day and inter-day variations were $0.05 \mu \mathrm{g} \mathrm{min}-1$ and $0.9 \mu \mathrm{g} \mathrm{min}^{-1}$, respectively (10 replicate analyses of the operative blank). To reduce the effect of the drift variability as much as possible, the measurement of the operative blank was carried out every two samples, and the KF curve of each sample (water vs. time) was obtained by subtracting the blank value to each point of the graph (see Fig. 1). This process allows a direct reading of the water amount on the y-axes of the graph; also, this method allows a direct subtraction of the water contribution due to the humidity of air inside the vial, the adsorption on the vial walls and the content of the plastic vial cap.

The limit of detection (LOD) and limit of quantification (LOQ) were calculated as three times and ten times the standard deviation of the blank (10 replicates). For a typical intra-day variability we obtained the following results: $\mathrm{LOD}=7 \mu \mathrm{g} ; \mathrm{LOQ}=25 \mu \mathrm{g}$.

\subsection{Real $\mathbf{P M}_{10}$ samples}

Twenty pairs of equivalent real PM samples were collected during the period November-Dicember 2011 in three different geographical areas. The location in Rome (Central Italy, $41^{\circ} 54^{\prime} 03.69^{\prime \prime} \mathrm{N}, 12^{\circ} 30^{\prime} 44.93^{\prime \prime} \mathrm{E}$ ) was a traffic site, about 50 meter from the nearest road (8 pairs of samples); the location in Ferrara (Po valley, Northern Italy, $44^{\circ} 50^{\prime} 55.44^{\prime \prime} \mathrm{N}$, $11^{\circ} 33^{\prime} 40.96^{\prime \prime} \mathrm{E}$ ) was an industrial site, about $5 \mathrm{~km}$ from the city center and $1 \mathrm{~km}$ from the nearest industrial plant (10 pairs); the location in Tel Aviv (Israel, $32^{\circ} 06^{\prime} 54.16^{\prime \prime} \mathrm{N}$, $\left.34^{\circ} 48^{\prime} 16.74^{\prime \prime} \mathrm{E}\right)$ was the roof of the Tel Aviv University (2 pairs).

Daily $\mathrm{PM}_{10}$ samples were collected on $47 \mathrm{~mm}$ diameter PTFE membranes, $1 \mu \mathrm{m}$ pore size (PALL Corporation, USA) by means of dual-channel samplers (HYDRA Dual Sampler, FAI Instruments, Fontenuova, Rome, I) equipped with two independent $\mathrm{PM}_{10}$ sampling heads compliant with EN 12341 (1998). In Rome and Tel Aviv the two channels were operated at the flow rate of $2.3 \mathrm{~m}^{3} \mathrm{~h}^{-1}$. In Ferrara, which is characterized by very high relative humidity, the sampling heads were modified in order to reduce the flow rate to $1.15 \mathrm{~m}^{3} \mathrm{~h}^{-1}$ and to avoid clogging of the sampling membranes.

An additional collection of six parallel samples was carried during the period 14-20 December 2011 at the Ferrara site, by using three HYDRA Dual Samplers placed 

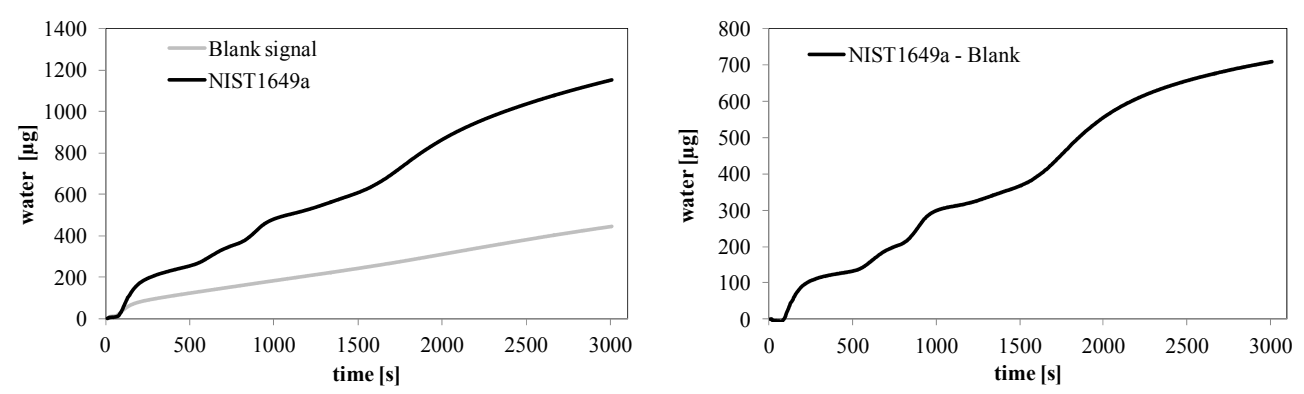

Fig. 1. Karl-Fisher analysis of the reference material NIST1649a. Left panel: original sample signal and blank signal. Right panel: sample signal after blank subtraction.

side-by-side. These samples were used to evaluate the effect of sample conservation.

Teflon filters were allowed to equilibrate for two days at $20{ }^{\circ} \mathrm{C}$ and $50 \% \mathrm{RH}$ before weighting. After sampling, filters were placed in Petri dishes and stored at $5^{\circ} \mathrm{C}$. Different procedures were used to evaluate the effect of storage conditions. Before the analysis all samples were re-equilibrated and re-weighted and the plastic rings of the filters were cut off by using a steel scalpel.

\section{Results and discussion}

\subsection{Method optimization}

The proposed method was optimized by using the Reference Material NIST1649a (National Standard Institute of Technology - USA), consisting of urban atmospheric particulate matter. Although its water content is not certified and it show some differences with respect to real $\mathrm{PM}_{10}$ samples (Canepari et al., 2006), this material makes it possible to perform the optimization phases on a rather representative homogeneous material.

The first optimization phase concerned the heating ramp and was aimed to obtain a satisfactory separation of the different water contributions to atmospheric PM. Figure 2 shows some examples of thermal ramp (left panels) and of KF curves obtained when applying the ramp to NIST 1649a (right panels). The total amount of water was $100 \pm 6 \mathrm{~g} \mathrm{~kg}^{-1}$, irrespective of the selected ramp. Instead, the curve profile strongly depends on the thermal ramp, as shown by the drift graph (grey lines in Fig. 2). When the heating temperature is constant, the operational mode generally used in this type of instruments, we obtain only one signal that is relative to the total water amount (Fig. 2, upper panels). The use of a linear thermal ramp allows the differentiation of several water contributions that are released from the sample at increasing temperatures (Fig. 2, middle panels). In these conditions, however, the contributions are insufficiently separated. It is worth noting that this linear ramp was used in previous scientific works regarding the TG analysis of NIST 1648 (Matuschek et al., 2004; Perrino et al., 2012). These papers reported two well-defined weight losses in the range $80^{\circ}-$ $120^{\circ} \mathrm{C}$ and $150^{\circ}-180^{\circ} \mathrm{C}$, which were attributed to particlebound water, and one wider loss in the range $225^{\circ} \mathrm{C}-310^{\circ} \mathrm{C}$ that was due to the release of several organic and inorganic species, with a possible contribution of crystallization water. Although the results obtained by KF and TG are qualitatively similar, the separation of the water contributions by the KF method is lower, probably because of a higher thermal inertia in the heat transfer to the sample.

The lower panels of Fig. 2 reports the optimized thermal ramp, obtained by a trial and error procedure, that was used to perform all subsequent analyses $\left(5 \mathrm{~min}\right.$ at $50^{\circ} \mathrm{C}$, from $50^{\circ} \mathrm{C}$ to $120^{\circ} \mathrm{C}$ at $14^{\circ} \mathrm{C} \mathrm{min}-1,5 \mathrm{~min}$ at $120^{\circ} \mathrm{C}$, from $120^{\circ} \mathrm{C}$ to $180^{\circ} \mathrm{C}$ at $12^{\circ} \mathrm{C} \mathrm{min}^{-1}, 2$ min at $180^{\circ} \mathrm{C}$, from $180^{\circ} \mathrm{C}$ to $250^{\circ} \mathrm{C}$ at $14^{\circ} \mathrm{C} \mathrm{min}^{-1}, 20 \mathrm{~min}$ at $250^{\circ} \mathrm{C}$ ). In these conditions, we obtained a significant improvement in the analytical resolution, and a profile very similar to that obtained by TG (Perrino et al., 2012). The first peak in the drift graph, which had not been detected by the TG analysis, identifies water that can be desorbed at low temperature $\left(50^{\circ} \mathrm{C}\right)$, probably due to moisture weakly adsorbed on the particles. The following three peaks (in the range 400-700 s, 700-1100 s, $1100-2300 \mathrm{~s}$ ) are in very good agreement with the results of the TG analysis and confirm the presence of different water contributions, bound to atmospheric particles with different strength.

\subsection{Method validation}

\subsubsection{Recovery}

To calculate the exactness, we used two standard materials (HYD e WSO) containing different amounts and qualities of water. Figure 3 reports the KF curves and the drift graphs of the two certified materials. HYD (upper graph) shows only one water contribution, desorbing over $200^{\circ} \mathrm{C}$, that is due to crystalization water. WSO (lower graph) shows two different contributions: the first one, weakly retained, is released at the beginning of the analytical run at about $50^{\circ} \mathrm{C}$, the second one is released in the range $500-800 \mathrm{~s}$, at the temperature of about $120^{\circ} \mathrm{C}$. 

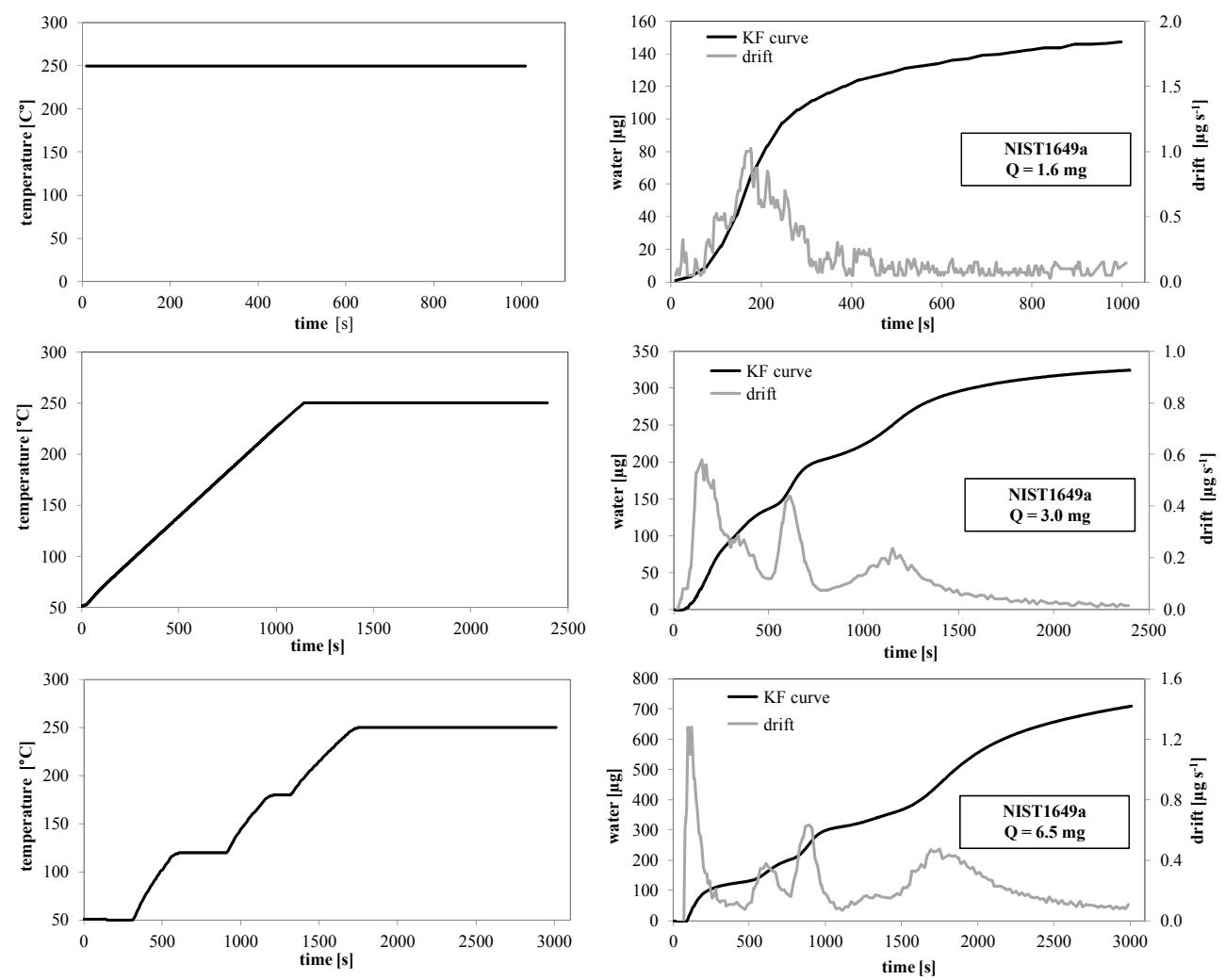

Fig. 2. Different thermal ramps (left panels) and resulting Karl-Fisher curves (right panels) for the analysis of Reference Material NIST1649a.

Table 1. Recovery of water from standard materials HYDRANAL (HYD) and Water Standard Oven (WSO). $N=10$.

\begin{tabular}{lcccc}
\hline & & $\begin{array}{c}\text { Certified } \\
\mu \mathrm{g}\end{array}$ & $\begin{array}{c}\text { Measured } \\
\mu \mathrm{g}\end{array}$ & $\begin{array}{c}\text { Recovery } \\
\%\end{array}$ \\
\hline \multirow{2}{*}{ HYD } & Low $(5 \mathrm{mg})$ & $278 \pm 3$ & $272 \pm 15$ & $98 \pm 6$ \\
& High (50 mg) & $2775 \pm 25$ & $2817 \pm 67$ & $102 \pm 3$ \\
\multirow{2}{*}{ WSO } & Low (10 mg) & $100 \pm 3$ & $101 \pm 8$ & $101 \pm 11$ \\
& High (50 mg) & $500 \pm 15$ & $497 \pm 28$ & $99 \pm 9$ \\
\hline
\end{tabular}

Table 1 shows the recovery of different amounts of the two standard materials. We did not consider amounts lower than $5 \mathrm{mg}$ in order to avoid the introduction of a high uncertainty contribution due to the gravimetric determination and transfer of very small sample amounts. In all cases the recovery was close to $100 \%$, while the repeatability was better for HYD (high amounts: about $3 \%$; low amounts: about $6 \%$ ) than for WSO (high amounts: about $9 \%$; low amounts: about $11 \%$ ), probably because of the lower stability of the water contained in WSO.

A further validation phase concerned the recovery from silica and alumina, which are among the hydrophilic species contained in PM. These compounds are thermally stable and available on the market at high purity level; it is thus possible to carry out a gravimetric determination of the water that
Table 2. Comparison of gravimetric and Karl Fisher determination of the water content. $N=10$.

\begin{tabular}{lccc}
\hline & \multicolumn{2}{c}{ Water content $\mathrm{g} \mathrm{Kg}^{-1}$} & Recovery $\%$ \\
\hline & Gravimetry & Karl Fisher & \\
$\mathrm{SiO}_{2}$ & $46 \pm 1$ & $45 \pm 3$ & $98 \pm 9$ \\
$\mathrm{Molecular} \mathrm{sieves}$ & $165 \pm 4$ & $167 \pm 6$ & $101 \pm 6$ \\
$\mathrm{Al}_{2} \mathrm{O}_{3}$ & $50 \pm 2$ & $48 \pm 2$ & $96 \pm 8$ \\
\hline
\end{tabular}

is desorbed when heating in oven $\left(105^{\circ} \mathrm{C}\right.$ for 24 hours). We also tested the molecular sieves used to dry the carrier gas of the KF (silicate with inorganic binder), in order to verify the influence of the material porosity on the profile of the KF curve. The KF curves obtained for these materials are shown in Fig. 4. All three materials show a contribution in the range $0-500 \mathrm{~s}$, probably due to moisture weakly adsorbed on the particles; the following part of the curves, instead, are quite different. The curve of silica (upper graph) shows only a further single contribution in the range 500-1000 s. Molecular sieves (middle graph) show a very similar behavior in the first part of the curve; with respect to silica, however, molecular sieves release a relevant amount of water also in the second part of the analysis (1000-1500 s), likely due to the release of water adsorbed inside pores. Alumina shows the same profile in the range 500-1000 s (lower graph), but also two other 

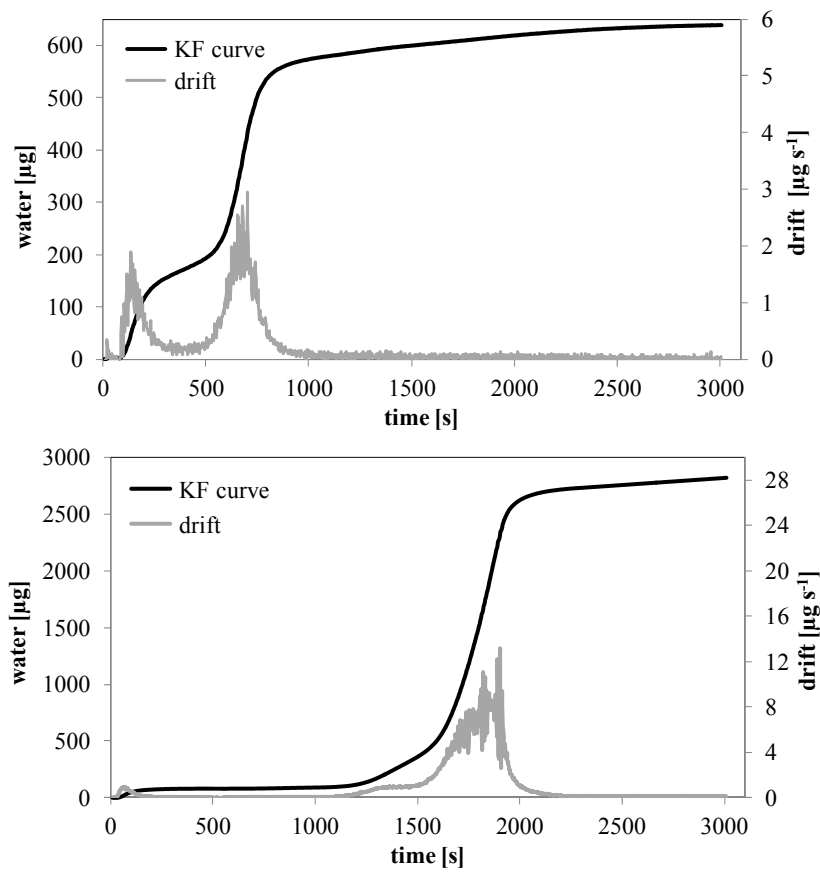

Fig. 3. Karl-Fisher curves of about $50 \mathrm{mg}$ of standard materials HYD (upper panel) and WSO (lower panel).

more retained contributions, not completely separated, between 1000 and $2300 \mathrm{~s}$, probably due to the presence of active sites of different strength.

Table 2 reports the recovery values for these materials. Also in this case the method shows good performance, with recoveries higher than $95 \%$ and repeatability around $6 \%$. It is worth noting that the results reported in Table 2 refer to very variable sample amounts $(5-100 \mathrm{mg})$ and to measured water amounts in the range $0.3-7 \mathrm{mg}$. The shape of the curves and the recovery values do not depend on the sample weight, indicating robustness and wide linearity range of the proposed method.

\subsubsection{Interferences}

It is worth noting that the KF method suffers from the interference of some classes of compounds, both organic and inorganic (EPA Method 9000, 2007), some of which are likely found in PM samples (aldehydes, ketones, carbohydrates, $\mathrm{Fe}(\mathrm{III})$ and $\mathrm{Cu}(\mathrm{II})$ salts). Most of these species are not able to interfere in analytical techniques based on heating due to their very low vapour pressure (levoglucosan, glucose, fructose, sucrose) (Chow et al., 2007). As far as carbonyl compounds are concerned, the species that reach high atmospheric concentration are mostly in the vapor phase (Levart and Veber, 2001). Some Authors highlight the presence of some semi-volatile ketones (n-alcan-2ones and o-Hydrocarbons Polycyclic Aromatics) (SchnelleKreis et al., 2005, 2007), but the atmospheric concentration
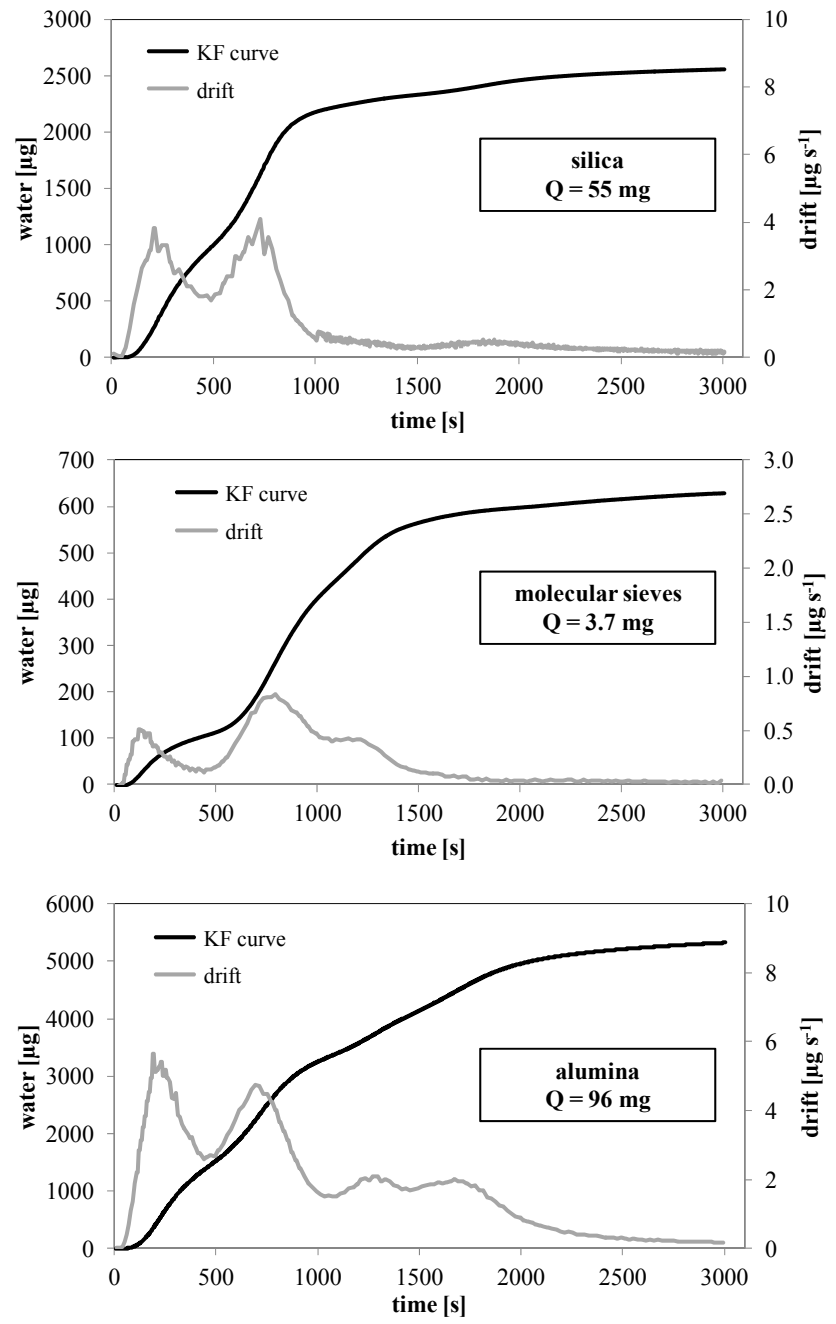

Fig. 4. Karl-Fisher curves of $\mathrm{SiO}_{2}$ (upper panel), molecular sieves (middle panel) and $\mathrm{Al}_{2} \mathrm{O}_{3}$ (lower panel).

of these species is usually very low (a few tenths of $\mathrm{ng} \mathrm{m}^{-3}$ for 6,10,14-trimethylpentadecan-2-one, the most abundant species) and their possible interference is well below the quantification limit of the method. Another possible analytical artifact might derive from the formation of water during the heating of hydroxyl compounds (Pavlath and Gregorski, 1985). Also in this case, the atmospheric concentration of these species is generally too low to be responsible for an appreciable artifact (Moreira dos Santos et al., 2002).

The possible positive interference of iodine reduction reaction due to ammonia is also highlighted in the EPA Method 9000 (2007). In the temperature range of the proposed KF method, ammonia is released from secondary ammonium salts, which constitute a relevant fraction of atmospheric PM (Perrino et al., 2012). To verify this hypothesis, the method was applied to pure $\mathrm{NH}_{4} \mathrm{NO}_{3},\left(\mathrm{NH}_{4}\right)_{2} \mathrm{SO}_{4}$ and $\mathrm{NH}_{4} \mathrm{Cl}$ salts. Measured amounts of water were $0.9 \pm 0.07 \%$ for chloride, $1.6 \pm 0.1 \%$ for nitrate and $8.5 \pm 0.4 \%$ for sulphate, values 
that are consistent with the hygroscopicity of these salts. As reported in Perrino et al. (2012), at the maximum operative temperature of the oven $\left(250^{\circ} \mathrm{C}\right)$ the thermal release of ammonia from $\mathrm{NH}_{4} \mathrm{Cl}$ and $\mathrm{NH}_{4} \mathrm{NO}_{3}$ is almost quantitative, while it is about $20 \%$ from $\left(\mathrm{NH}_{4}\right)_{2} \mathrm{SO}_{4}$. To evaluate the interference of ammonia we considered $\mathrm{NH}_{4} \mathrm{Cl}$, that is the species that yields the lowest signal. Considering that all the ammonia content of the salt is transferred in the cell, we obtain a maximum signal equivalent to a water amount of $0.9 \%$ of the salt weight.

Considering a total ammonium amount on the sampled filter as high as $500 \mu \mathrm{g}$ (very high values, corresponding to an ammonia concentration of about $10 \mu \mathrm{g} \mathrm{m}^{-3}$ for 24-h samplings at the flow rate of $2.3 \mathrm{~m}^{3} \mathrm{~h}^{-1}$ ) even if the measured signal were totally attributed to interfering ammonia (anhydrous salt) we would obtain a signal equivalent to only $14 \mu \mathrm{g}$ of water $(0.9 \%$ of $500 \mu \mathrm{g}$ multiplied by the molecular weight of ammonium chloride and divided by the molecular weight of ammonium). We can thus conclude that ammonia interference, if present, would in any case be negligible.

\subsection{Real samples}

Some preliminary tests addressed the analysis of the most common sampling media (Teflon and quartz) and the effect of the sampled filters conservation procedure on the water content.

The profile of KF curves from the analysis of quartz fiber filters resembles the profile of molecular sieves, in agreement with the common siliceous composition. Blank values, as expectable, were quite high (about $1400 \mu \mathrm{g}$ per filter). The profile of Teflon membrane filters, instead, was indistinguishable from the blank, both before and after conditioning at $50 \% \mathrm{RH}$, in agreement with their hydrophobic characteristics. Teflon filters were thus considered as suitable media for PM sampling aimed at water content determination.

The influence of the sample conservation procedure was studied by analyzing six groups of six equivalent $\mathrm{PM}_{10}$ samples sampled side-by-side. One filter of each group was removed from the sampler immediately after the end of the sampling, conditioned at $20^{\circ} \mathrm{C}$ and $50 \% \mathrm{RH}$ for 48 hours and then analyzed. The other five filters were left inside the unloader of the sampler until the end of the last sampling period. A second element of each group was directly conditioned and analyzed, while other three filters were placed inside Petri dishes, sealed with parafilm and kept for three months at ambient temperature, $5^{\circ} \mathrm{C}$ or $-18^{\circ} \mathrm{C}$, respectively. The last element of each group was kept for six months at $5{ }^{\circ} \mathrm{C}$, before being conditioned and analysed. No significant differences were observed among the six profiles of each group of samples; the analytical repeatability was about $10 \%$, indicating a good stability of the water retained by the particles. Storage temperature was then set at $5{ }^{\circ} \mathrm{C}$.

The validation of the method on real samples was completed by analyzing 20 pairs of $\mathrm{PM}_{10}$ samples collected at

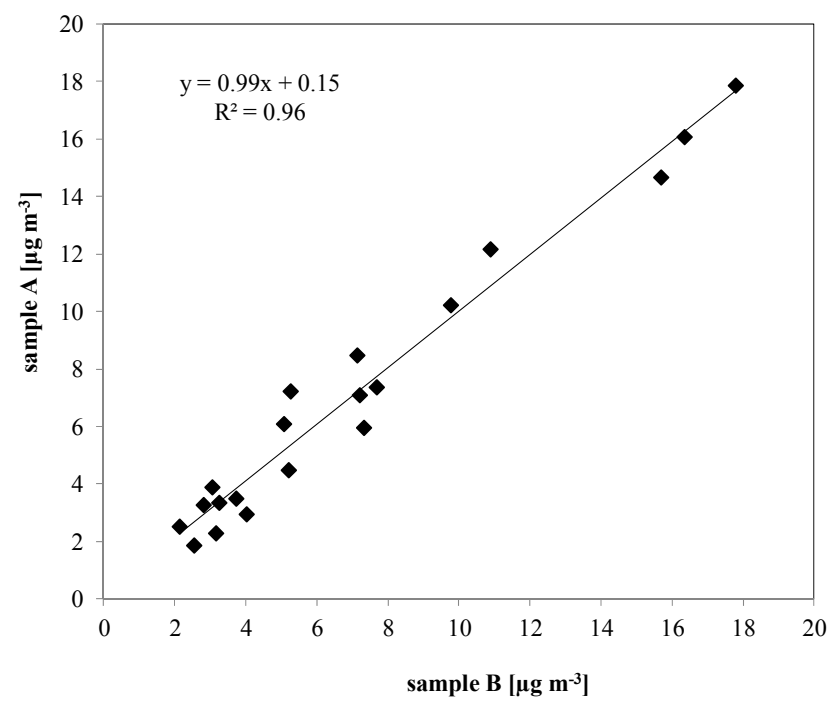

Fig. 5. Scatter plot of the water content of $\mathrm{PM}_{10}$ samples collected side-by-side (20 pairs).

very different locations: a traffic site in Rome, an industrial site in Ferrara (Po Valley, (Northern Italy), a urban site in Tel Aviv (Israel). The collected amount of dust was variable (range: $0.5-2.9 \mathrm{mg}$ ); the wide differences in the emission sources and meteo-climatic conditions at these three sites should also assure a variety in the chemical composition of the collected dust.

According to EN 14902 (2005), the repeatability was calculated as follows:

$r_{\text {rel }}=\frac{r}{\bar{X}} \cdot 100 ; r=\sqrt{\frac{\sum_{i=1}^{N}\left(m_{i A}-m_{i B}\right)^{2}}{2 N}} ;$

$\bar{X}=\frac{\sum_{i=1}^{N}\left(m_{i A}+m_{i B}\right)}{2 N}$

where $m_{i A}$ and $m_{i B}$ are the water amount determined on each component of the filter pair, and $N$ is the total number of $\mathrm{PM}_{10}$ sample pairs $(N=20)$. The obtained value $\left(r_{\text {rel }}=10.2 \%\right)$ was satisfactory and consistent with the repeatability values determined for NIST 1649a and for pure materials.

Figure 5 shows the scatter plot of the results obtained from each filter pair. The regression parameters (slope: 0.98 ; intercept: $0.15 \mu \mathrm{g} \mathrm{m}^{-3}$; Pearson's coefficient: 0.96) confirm the good analytical performance of the method also when applied to real samples.

It is worth noting that the water content of our samples was very variable and reached remarkably high values, especially in Ferrara and Tel Aviv. In general, water constituted about $3-4 \%$ of the total PM mass of the samples collected in Rome, while in Ferrara and in Tel Aviv we obtained percentages 

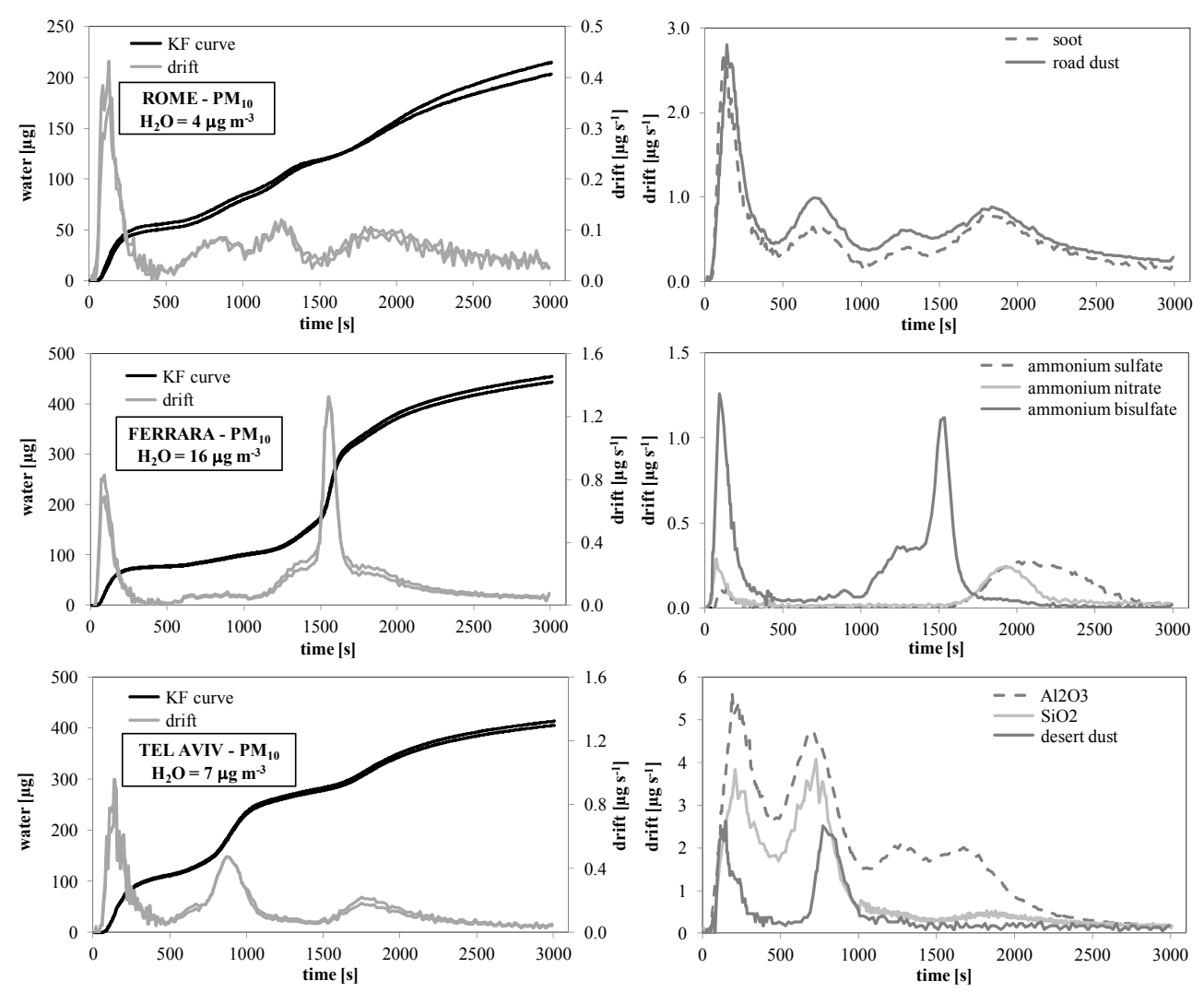

Fig. 6. Examples of the Karl-Fisher curves of $\mathrm{PM}_{10}$ paired samples collected side-by-side at the three sites (left panels) and drift profiles of some single hydrophilic components of PM (right panels).

over $10 \%$, with a contribution of more than $20 \mu \mathrm{g} \mathrm{m}{ }^{-3}$ to the environmental concentration of $\mathrm{PM}_{10}$.

In the left panel of Fig. 6 we report examples of the KF curves obtained from pairs of samples collected at the three sites. The KF profiles of the two elements of each pair are alike; the three examples, however, show very different profiles.

The first water contribution, in the range $0-500 \mathrm{~s}$, is due to weakly adsorbed moisture and is contained in all samples; the amounts are in the range $50-150 \mu \mathrm{g}$. From $500 \mathrm{~s}$ on, the profiles become characteristics of the sampling site, with small inter-day variations. The release of water from the samples collected in Rome occurs in many steps, during the whole analytical run. The samples collected in Ferrara show a sharp signal at about $1500 \mathrm{~s}$, superimposed to a broader signal in the interval 1000-2000 s. Tel Aviv samples show, instead, two well-defined contributions, in the range $700-1100 \mathrm{~s}$ and after $1500 \mathrm{~s}$.

Since these differences are very probably due to a different chemical composition of PM at the three sites, we carried out some exploratory qualitative analyses of some hydrophilic components of PM (see the drift profiles of all the analyzed materials in the Supplementary Material). The most interesting results are reported in the right panels of Fig. 6.
The profiles of soot (sampled inside the exhaust silencer of a diesel car) and of road dust (sampled at the kerbside of a high-density traffic road) were very similar to the profile of $\mathrm{PM}_{10}$ sampled in Rome, in agreement with the relevance of local traffic sources in the composition of PM in this area (Canepari et al., 2009; Perrino et al., 2009). Water contained in secondary salts and in some hydrophilic species (carbohydrates and dicarboxylic acids) is detected mainly in the range $1000-2000 \mathrm{~s}$. It is likely that the curve obtained by analyzing the samples collected in Ferrara is due to water associated to these compounds. In the area of Ferrara, in fact, particularly during the winter, the formation of organic and inorganic secondary species is favored by the occurrence of frequent and long-lasting atmospheric stability conditions (Matta et al., 2003). Saharan dust (collected at Erfoud, Morocco) in agreement with its composition, shows a profile close to those of $\mathrm{SiO}_{2}$ and $\mathrm{Al}_{2} \mathrm{O}_{3}$, with a sharp contribution between 700 and $1100 \mathrm{~s}$. This contribution is very similar to one of the contributions detected in the filters collected in Tel Aviv, where the dust intrusions from the nearby desert are very frequent (Ganor, 1994). It is worth noting that the last contribution in these filters resembles the road dust and soot profile, as expected for an urban site. 


\section{Conclusions}

The described method, employing a coulometric Karl Fisher systems, allows a direct determination of water in atmospheric particulate matter. It shows a good analytical performance, does not require any filter pre-treatment and is applicable to routine field studies.

The method was applied to a series of $\mathrm{PM}_{10}$ samples collected in different geographical areas. The results of these field studies show that the water content of PM samples is variable and can reach values over $20 \mu \mathrm{g} \mathrm{m}^{-3}$. Such an amount of water constitute a relevant fraction of the total mass of PM and may seriously affect the exceedance of the regulatory concentration limit values.

The use of a thermal ramp for the desorption of water allows the separation of different water contributions that are bound to atmospheric particles with different strength. The profile of the curve resulted to be characteristic of the sampling site; the amount and variety of water is then probably linked to the chemical characteristics of the dust.

\section{Supplementary material related to this article is available online at: http://www.atmos-chem-phys.net/13/ 1193/2013/acp-13-1193-2013-supplement.pdf.}

Acknowledgements. This work was financed by private founds. The Authors gratefully acknowledge C. Ragazzini and G. Simonetti for their collaboration and D. Petrocchi (Metrohm) for his valuable suggestions.

Edited by: M. C. Facchini

\section{References}

Almeida, S. M., Pio, C. A., Freitas, M. C., Reis, M. A., and Trancoso, M. A.: Approaching $\mathrm{PM}_{2.5}$ and $\mathrm{PM}_{2.5}-10$ source apportionment by mass balance analysis, principal component analysis and particle size distribution, Sci. Total Environ., 368, 663-674, 2006.

Ansari, A. S. and Pandis, S. N.: Water Absorption by Secondary Organic Aerosol and Its Effect on Inorganic Aerosol Behavior, Environ. Sci. Technol., 34, 71-77, 2000.

Baek, B. H., Aneja, V. P., and Tong, Q.: Chemical coupling between ammonia, acid gases, and fine particles, Environ. Pollut., 129, 89-98, 2004.

Balasubramanian, R., Qian, W. B., Decesari, S., Facchini, M. C., and Fuzzi, S.: Comprehensive characterization of $\mathrm{PM}_{2.5}$ aerosols in Singapore, J. Geohys. Res., 108, 4523-4539, 2003.

Canepari, S., Cardarelli, E., Pietrodangelo, A., and Strincone, M.: Determination of metals, metalloids and non-volatile ions in airborne particulate matter by a new two-step sequential leaching procedure. Part B: validation on real equivalent samples, Talanta, 69, 588-595, 2006.
Canepari, S., Pietrodangelo, A., Perrino, C., Astolfi, M. L., and Marzo, M. L.: Enhancement of source traceability of atmospheric PM by elemental chemical fractionation, Atmos. Environ. 43, 4754-4765, 2009.

Chow, J. C., Watson, J. G., and Lowenthal, D. H.: Loss of $\mathrm{PM}_{2.5}$ Nitrate from Filter Samples in Central California, J. Air Waste Manage. Assoc., 55, 1158-1168, 2005.

Chow, J. C., Yu, J. Z., Watson, J. G., Hang Ho, S. S., Bohannan, T. L., Hays, M. D., and Fung, K. K.: The application of thermal methods for determining chemical composition of carbonaceous aerosols: A review, J. Environ. Sci. Health., Part A, 42, 152115412007.

Decesari, S., Facchini, M. C., Matta, E., Lettini, F., Mircea, M., Fuzzi, S., Tagliavini, E., and Putaud, J. P.: Chemical features and seasonal variation of fine aerosol water-soluble organic compounds in the Po Valley, Italy, Atmos. Environ., 35, 3691-3699, 2001.

Dick,W. D., Saxena, P., and McMurry, P. H.: Estimation of water uptake by organic compounds in submicron aerosols measured during the Southeastern aerosol and visibility study, J. Geophys. Res., 105, 1471-1479, 2000.

EN12341: Air Quality. Determination of the PM10 fraction of suspended particulate matter - Reference method and field test procedure to demonstrate reference equivalence of measurement methods, Brussels, 1998.

EN 14902: 2005 Ambient air quality - standard method for the measurement of $\mathrm{Pb}, \mathrm{Cd}, \mathrm{As}$ and $\mathrm{Ni}$ in the PM10 fraction of suspended particulate matter, 2005.

EPA Method 9000: Determination of water in waste materials by Karl Fischer titration, 2007.

Fisher, K.: Neues Verfahren zur maßanalytischen Bestimmung des wassergehaltes von Flüssigkeiten und festen Körpern, Angew. Chem., 48, 394-396,1935.

Ganor, E.: The frequency of Saharan dust episodes over TelAviv, Israel, Atmos. Environ., 28, 2867-2871, 1994.

Gysel, M., Crosier, J., Topping, D. O., Whitehead, J. D., Bower, K. N., Cubison, M. J., Williams, P. I., Flynn, M. J., McFiggans, G. B., and Coe, H.: Closure study between chemical composition and hygroscopic growth of aerosol particles during TORCH2, Atmos. Chem. Phys., 7, 6131-6144, doi:10.5194/acp-7-61312007, 2007.

Harrison, R. M., Jones, A. M., and Lawrence, R. G.: A pragmatic mass closure model for airborne particulate matter at urban background and roadside sites, Atmos. Environ., 37, 4927-4933, 2003.

Hu, D., Chen, J., Ye, X., Li, L., and Yang, X.: Hygroscopicity and evaporation of ammonium chloride and ammonium nitrate: Relative humidity and size effects on the growth factor, Atmos. Environ., 45, 2349-2355, 2011.

Khlystov, A., Lin, M., Bolch, M. A., and Ma, Y.: Investigation of the positive artifact formation during sampling semi-volatile aerosol using wet denuders, Atmos. Environ., 43, 364-370, 2009.

Kitamori, Y., Mochida, M., and Kawamura, K.: Assessment of the aerosol water content in urban atmospheric particles by the hygroscopic growth measurements in Sapporo, Japan, Atmos. Environ., 43, 3416-3423, 2009.

Kreidenweis, S. M., Remer, L. A., Bruintjes, R., and Dubovik, O.: Smoke aerosol from biomass burning in Mexico: Hygroscopic smoke optical model, J. Geophys. Res., 106, 4831-4844, 2001. 
Levart, A. and Veber, M.: Determination of aldehydes and ketones in air samples using cryotrapping sampling, Chemosphere, 44, 701-708, 2001.

Matta, E., Facchini, M. C., Decesari, S., Mircea, M., Cavalli, F., Fuzzi, S., Putaud, J.-P., and Dell'Acqua, A.: Mass closure on the chemical species in size-segregated atmospheric aerosol collected in an urban area of the Po Valley, Italy, Atmos. Chem. Phys., 3, 623-637, doi:10.5194/acp-3-623-2003, 2003.

Matuschek, G., Saritas, Y., Karg, E., and Schroeppel, A.: Characterisation of aerosol particles using combined termoanalitycal techniques, J. Therm. Anal. Calorim., 78, 575-586, 2004.

Moreira dos Santos, C. Y., de Almeida Azevedo, D., and Radler de Aquino Neto, F.: Selected organic compounds from biomass burning found in the atmospheric particulate matter over sugarcane plantation areas, Atmos. Environ., 36, 3009-3019, 2002.

Ohta, S., Hori, M., Yamagata, S., and Murao, N.: Chemical characterization of atmospheric fine particles in Sapporo with determination of water content, Atmos. Environ., 32, 1021-1025, 1998.

Pathak, R. K., Wu, W. S., and Wang, T.: Summertime $\mathrm{PM}_{2.5}$ ionic species in four major cities of China: nitrate formation in an ammonia-deficient atmosphere, Atmos. Chem. Phys., 9, 17111722, doi:10.5194/acp-9-1711-2009, 2009.

Pavlath, A. E. and Gregorski, K. S.: Atmospheric pyrolysis of carbohydrates with thermogravimetric and mass spectrometric analyses, J. Anal. Appl. Pyrolysis, 8, 41-48, 1985.

Perrino, C., Canepari, S., Cardarelli, E., Catrambone, M., and Sargolini, T.: Inorganic constituents of urban air pollution in the Lazio region (Central Italy), Environ. Monit. Assess., 128, 133115, 2007.

Perrino, C., Canepari, S., Catrambone, M., Dalla Torre, S., Rantica, E., and Sargolini, T.: Influence of natural events on the concentration and composition of atmospheric particulate matter, Atmos. Environ., 43, 4766-4779, 2009.

Perrino, C., Marconi, E., Tofful, L., Farao, C., Materazzi, S., and Canepari, S.: Thermal behavior of atmospheric particulate matter, Atmos. Environ., 54, 36-43, 2012.

Perrino, C., Canepari, S., and Catrambone, M.: Comparing performance of Teflon and quartz membrane filters collecting PM: influence of atmospheric water, Aerosol Air Qual. Res., 13, 137147, 2013.

Perrone, M. G., Larsen, B. R., Ferrero, L., Sangiorgi, G., De Gennaro, G., Udisti, R., Zangrando, R., Gambaro, A., and Bolzacchini, E.: Sources of high $\mathrm{PM}_{2.5}$ concentrations in Milan, Northern Italy: Molecular marker data and CMB modeling, Sci. Total Environ., 414, 343-355, 2012.

Pilinis, C., Pandis, S. N., and Seinfeld, J. H.: Sensitivity of direct climate forcing by atmospheric aerosols to aerosol size and composition, J. Geophys. Res., 100, 18739-18754, 1995.

Rees, S. L., Robinson, A. L., Khlystov, A., Stanier, C. O., and Pandis, S. N.: Mass balance closure and the $\mathrm{PM}_{2.5}$ Federal Reference Method in Pittsburgh, Pennsylvania, Atmos. Environ., 38, 3305-3318, 2004.
Sasaki, K. and Sakamoto, K.: Diurnal characteristics of suspended particulate matter and $\mathrm{PM}_{2.5}$ in the urban and suburban atmosphere of the Kanto plain, Japan, Water Air Soil Pollut., 171, 29-47, 2006.

Schnelle-Kreis, J., Sklorz, M., Peters, A., Cyrys, J., and Zimmermann, R.: Analysis of particle- associated semi-volatile aromatic and aliphatic hydrocarbons in urban particulate matter on a daily basis, Atmos. Environ., 39, 7702-7714, 2005.

Schnelle-Kreis, J., Sklorz, M., Orasche, J., Stolzel, M., Peters, A., and Zimmermann, R.: Semi volatile Organic Compounds in Ambient $\mathrm{PM}_{2.5}$. Seasonal Trends and Daily Resolved Source Contributions, Environ. Sci. Technol., 4, 3821-3828, 2007.

Sloane, C. S. and Wolfe, G. T.: Prediction of ambient light scattering using a physical model responsive to relative humidity: Validation with measurements from Detroit, Atmos. Environ., 19, 669-680, 1985.

Speer, R. E., Barnes, H. M., and Brown, R.: An instrument for measuring the liquid content of aerosols, Aerosol Sci.Technol., 27, 50-61, 1997.

Speer, R. E., Edney, E. O., and Kleindienst, T. E.: Impact of organic compounds on the concentration of liquid water in ambient $\mathrm{PM}_{2.5}$, J. Aerosol Sci., 34, 63-77, 2003.

Squizzato, S., Masiol, M., Brunelli, A., Pistollato, S., Tarabotti, E., Rampazzo, G., and Pavoni, B.: Factors determining the formation of secondary inorganic aerosol: a case study in the Po Valley (Italy), Atmos. Chem. Phys. Discuss., 12, 16377-16406, doi:10.5194/acpd-12-16377-2012, 2012.

Stanier, C., Khlystov, A., Chan, W. R., Mandiro, M., and Pandis, S. N.: A method for the in-situ measurement of aerosol water content of ambient aerosols: The Dry-Ambient Aerosol Size Spectrometer (DAASS), Aerosol Sci. Technol., 38, 215-228, 2004.

Swietlicki, E., Zhou, J., Berg, O. H., Martinsson, B. G., Frank, G., Cederfelt, S., Dusek, U., Berner, A., Birmili, W., Wiedensohler, A., Yuskiewicz, B., and Bower, K. N.: A closure study of submicrometer aerosol particle hygroscopic behavior, Atmos. Res., 50, 205-240, 1999.

Tsai, Y. I. and Kuo, S. C.: Aerosol Water Content and Chemical Composition in a Metropolitan and a Coastal Area in Southern Taiwan, Atmos. Environ., 39, 4827-4839, 2005.

Tsyro, S. G.: To what extent can aerosol water explain the discrepancy between model calculated and gravimetric PM10 and $\mathrm{PM}_{2.5}$, Atmos. Chem. Phys., 5, 515-532, doi:10.5194/acp-5515-2005, 2005.

Vecchi, R., Valli, G., Fermo, P., D’Alessandro, A., Piazzalunga, A., and Bernardoni, V.: Organic and inorganic sampling artefacts assessment, Atmos. Environ., 43, 1713-1720, 2009.

Yuc, X. Y., Lee, T., Ayres, B., Kreidenweis, S. M., Malm, W., and Collett Jr., J. L.: Loss of fine particle ammonium from denuded nylon filters, Atmos. Environ., 40, 4797-4807, 2006. 